\title{
Isolated Intraconal Meningioma
}

\author{
Mohammad Taher Rajabi ${ }^{1}$, MD; Kasra Cheraqpour ${ }^{1}$, MD, MPH; S. Saeed Mohammadi ${ }^{1,6}$, MD \\ Mohammad Veshagh $^{2}$, MD; Seyedeh Zahra Poursayed Lazarjani ${ }^{1,3}$, MD; Farideh Hosseinzadeh ${ }^{4}$, MD \\ Fahimeh Asadi Amoli ${ }^{5}$, MD; Simindokht Hosseini ${ }^{1}$, MD
}

\author{
${ }^{1}$ Eye Research Center, Farabi Eye Hospital, Tehran University of Medical Sciences, Tehran, Iran \\ ${ }^{2}$ Ophthalmic Research Center, Research Institute for Ophthalmology and Vision Science, Labbafinejad Medical Center, Shahid \\ Beheshti University of Medical Sciences, Tehran, Iran \\ ${ }^{3}$ Department of Ophthalmology, Guilan University of Medical Sciences, Rasht, Iran \\ ${ }^{4}$ ENT and Head \& Neck Research Center, The Five Senses Health Institute, Iran University of Medical Sciences, Tehran, Iran \\ ${ }^{5}$ Pathology Department, Farabi Eye Hospital, Tehran University of Medical Sciences, Tehran, Iran \\ ${ }^{6}$ Department of Ophthalmology, Abadan University of Medical Sciences, Abadan, Iran \\ ORCID: \\ Mohammad Taher Rajabi: https://orcid.org/0000-0001-7379-6861 \\ Seyedeh Zahra Poursayed Lazarjani: https://orcid.org/0000-0003-4560-9787
}

\section{Abstract}

Purpose: To report a rare case of isolated intraconal meningioma.

Case Report: A 24-year-old woman presented with painless proptosis in her left eye which started and progressed during her pregnancy about 10 months ago. Hertel exophthalomometry revealed anterior displacement of the globe with $4 \mathrm{~mm}$ of proptosis which was remarkable. Magnetic resonance imaging (MRI) demonstrated an intraconal circumscribed oval-shaped mass with hypointense signals on T1-weighted images and hyperintense signals on T2-weighted images, mimicking cavernous hemangioma. This mass, however, was free of any connections to optic nerve or bones. Due to the imaging characteristics, more prevalent diagnoses like cavernous hemangioma were placed on the top of the differential diagnoses list. However, during the surgical excision, the tumor's consistency and gross features were not compatible with cavernous hemangioma. The pathologic findings instead determined meningotheliomatous meningioma, a very rare condition, which was far from our expectations prior to the surgery.

Conclusion: Ectopic orbital meningiomas are rare tumors that are not easily diagnosed without postoperative histopathology. Despite its low prevalence, they should be considered in the differential diagnosis list of intraconal masses with hypointense signals on T1-weighted images and hyperintense signals on T2-weighted images.

Keywords: Ectopic Meningioma; Intraconal Meningioma; Orbital Meningioma; Primary Meningioma

J Ophthalmic Vis Res 2021; 16 (4): 682-687 


\section{INTRODUCTION}

Orbital meningiomas account for $0.4-2 \%$ of all meningiomatous tumors. ${ }^{[1]}$ These lesions are further subdivided into three classifications. The first classification is primary optic nerve sheath meningiomas (ONSM) originating from the arachnoid layer of the optic nerve $(<30 \%$ of cases). The second classification is secondary ONSM arising from the sphenoid wing (e.g., intracranial meningiomas accounting for $<70 \%$ of orbital meningiomas). The last rare group is ectopic meningiomas which are free from any connections to the optic nerve or intracranial meninges $(<1 \%){ }^{[2-9]}$ Ectopic orbital meningioma is usually located on the medial part of the orbit. ${ }^{[10]}$ This uncommon entity of meningiomas usually reveals as a well-circumscribed mass but an ill-defined border does not rule out this type of tumor. ${ }^{[10]}$ Herein, we report a rare case of ectopic (isolated) intraconal meningioma.

\section{CASE REPORT}

A 24-year-old woman presented with painless proptosis in her left eye, which started and progressed during her pregnancy about 10 months ago. Her uncorrected- and best-corrected visual acuity (UCVA and BCVA) were 20/25 and 20/20, respectively. In addition, the relative afferent pupillary defect (RAPD) in the left eye was negative. While the Hertel exophthalmometry revealed an anterior displacement of the globe with $4 \mathrm{~mm}$ of proptosis, the fundoscopy showed a left optic disc edema. Other slit-lamp examinations were normal.

Magnetic resonance imaging (MRI) demonstrated an intraconal circumscribed oval-shaped mass with hypointense signals on T1-weighted images and hyperintense signals on T2-weighted images [Figure 1] mimicking cavernous hemangioma.

\section{Correspondence to:}

Seyedeh Zahra Poursayed Lazarjani, MD. Eye Research Center, Department of Eye, Amiralmomenin Hospital, School of Medicine, Guilan University of Medical sciences, Rasht 416584346, Iran.

E-mail: s.poursayed@gmail.com

Received: 04-03-2020Ａccepted: 23-12-2020

Access this article online

Website: https://knepublishing.com/index.php/JOVR

DOI: 10.18502/jovr.v16i4.9759
As a consequence, the patient underwent uncomplicated superomedial orbitotomy which resulted in the removal of a $3 \times 1 \times 0.5 \mathrm{~cm}$ necrotic white mass without any bleeding and which was also free of connections to the optic nerve sheath.

A histopathological examination showed tumoral cells with syncytial and whirling arrangement, indistinct cell membranes, eosinophilic cytoplasma, and rather uniform nuclei. Some intranuclear pseudoinclusions were also present. Mitotic figures were rare. Immunohistochemistry revealed positive staining for epithelial membrane antigen (EMA) a progesterone receptor (PR) [Figure 2] and negative staining for S100, CD34, and BCL2. Ki67 showed proliferative activity in about $1-2 \%$ of tumor cells. As a result, a meningotheliomatous meningioma (WHO grade 1) diagnosis was made.

Postoperative radiotherapy was performed on the orbital tumor bed. After a one-year follow-up, no complications or changes in the patient's perimetry, visual acuity, and RAPD were detected.

\section{DISCUSSION}

When assessing an intraconal mass with hypointense signals on T1-weighted images and hyperintense signals on T2-weighted images, several differential diagnoses should be considered, such as cavernous hemangioma, schwannoma, lymphoma, and neurofibroma. In our case, the orbital mass was intraconal without connections to the optic nerve or bones. Due to the imaging features of the lesion, a more prevalent diagnosis, such as cavernous hemangioma was expected. However, during the surgical excision of the lesion, the tumor's consistency and gross features were different from that of a cavernous hemangioma and the pathological evaluation of the mass determined meningotheliomatous meningioma.

This is an open access journal, and articles are distributed under the terms of the Creative Commons Attribution-NonCommercial-ShareAlike 4.0 License, which allows others to remix, tweak, and build upon the work non-commercially, as long as appropriate credit is given and the new creations are licensed under the identical terms.

How to cite this article: Rajabi MT, Cheraqpour K, Mohammadi SS, Veshagh M, Lazarjani SZP, Hosseinzadeh F, Amoli FA, Hosseini S. Isolated Intraconal Meningioma. J Ophthalmic Vis Res 2021;16:682-687. 

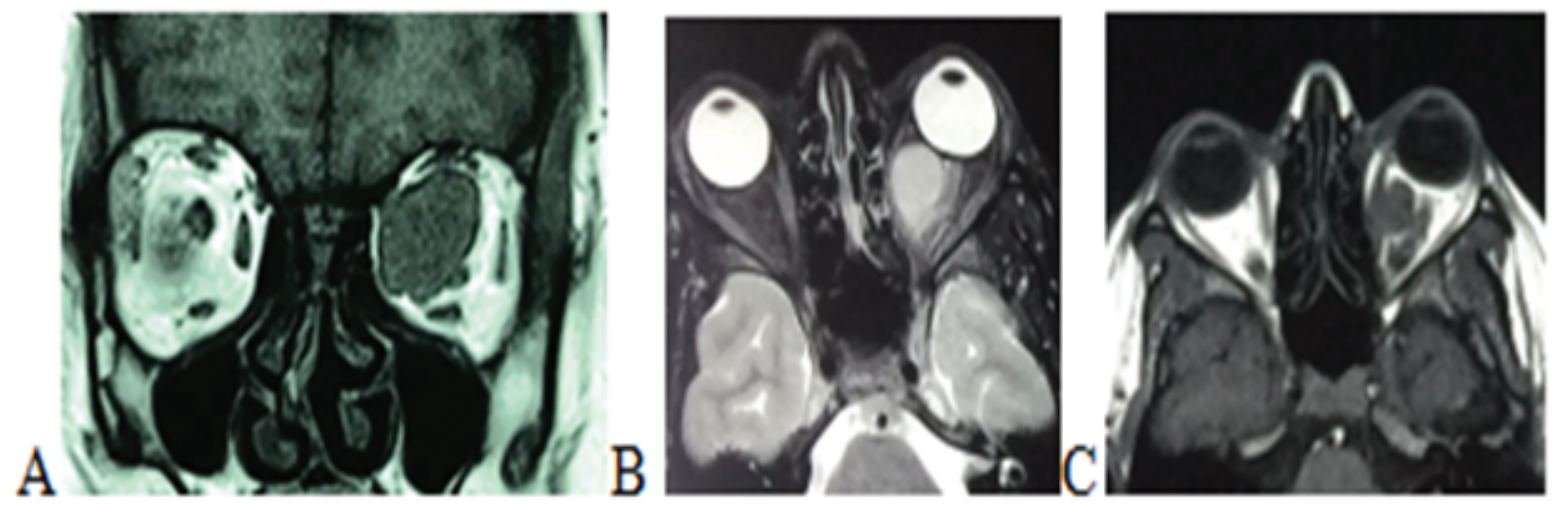

Figure 1. Orbital Magnetic Resonance Imaging (MRI). (A) Coronal image illustrating a superonasal intraconal mass on T1-weighted images which is separated from optic nerve. (B \& C) Axial image illustrates a hypointense oval-shaped intraconal mass on T1weighted images and hyperintense on T2-weighted images.
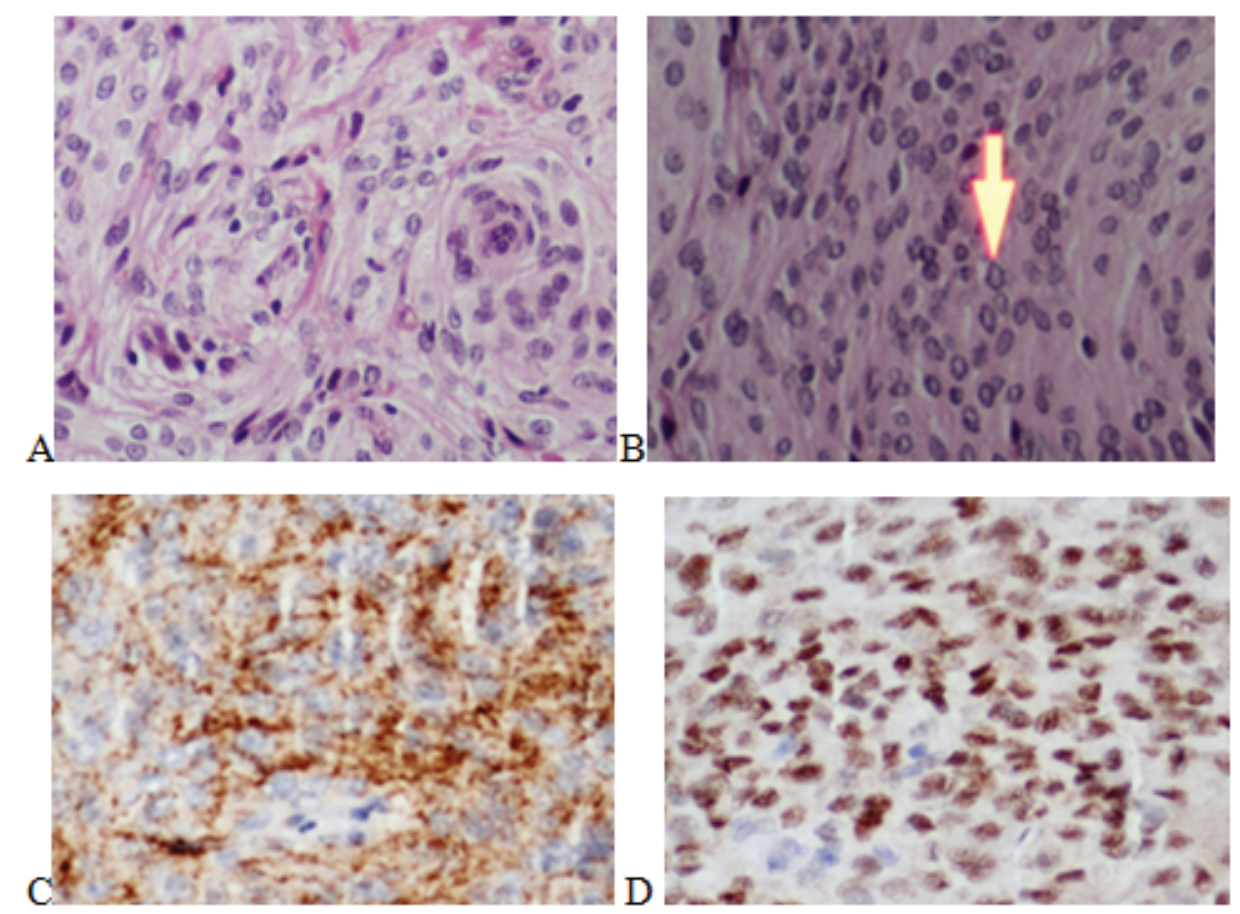

Figure 2. Histopathology. (A) Hematoxylin and Eosin (H\&E) staining illustrating meningioma, tumoral cells with syncytial and whirling arrangement. (B) H\&E staining showing intranuclear pseudo-inclusions. (C \& D) Immunohistochemistry illustrating positive staining for Epithelial Membrane Antigen (EMA) (cytoplasmic), Progesterone Receptor (PR) (nuclear), respectively.

As a result, our patient underwent an orbitotomy with a partial tumor resection due to its fragile nature. Systemic work up was normal and the patient was referred for adjunctive radiotherapy. Although recurrence is rare in cases of complete excision, it should be mentioned that incisional biopsy has been known to accelerate spreading and recurrence of the tumor. ${ }^{[11]}$

It should be mentioned that other possible diagnoses such as sclerosis or hyperplasia of the superior orbital rim or asymmetry of the sinuses ${ }^{[7]}$ were ruled out in our case.

Orbital meningiomas most commonly arise from the base of skull or optic nerve sheath while ectopic orbital meningiomas are extremely rare accounting for $<1 \%$ of cases. Many previous studies have reported ectopic orbital meningiomas being located along the medial wall and superonasal rim. ${ }^{[10]}$ Origin of ectopic meningiomas has always been debated. These 
Table 1. Brief review on recent reports

\begin{tabular}{|c|c|c|c|c|c|c|}
\hline No. ${ }^{[R e f]}$ & Patient & $\begin{array}{c}\text { History \& } \\
\text { Examination }\end{array}$ & VA & Imaging & Treatment & Outcome \\
\hline \multirow[t]{2}{*}{$\begin{array}{l}\text { Gündüz } \\
\text { et al }{ }^{[10]}\end{array}$} & $56 / F$ & $\begin{array}{l}* 3 \text { months of } \\
\text { slowly progressive } \\
\text { proptosis and } \\
\text { eyelid swelling }{ }^{*} 5 \\
\text { mm of proptosis } \\
\text { (OD) }\end{array}$ & $20 / 20$ & $\begin{array}{l}\text { *MRI: III-defined mass in the right } \\
\text { superior orbit with isointense } \\
\text { signals and respect to the orbital } \\
\text { fat and cerebral gray matter on } \\
\text { T1WI, hypointense signals on } \\
\text { T2WI, and moderate contrast } \\
\text { enhancement }{ }^{*} \mathrm{CT} \text { scan: } \\
\text { Superiorly located mass } \\
\text { producing thinning of the } \\
\text { overlying bone }\end{array}$ & $\begin{array}{l}\text { Subtotal resection } \\
\text { through } \\
\text { superonasal } \\
\text { orbitotomy }+ \\
\text { conventional } \\
\text { external beam } \\
\text { radiotherapy }\end{array}$ & $\begin{array}{l}\text { *74 months F/U } \\
\text { without } \\
\text { recurrence *VA of } \\
\text { CF at } 2 \text { meters } \\
\text { due to radiation } \\
\text { retinopathy }\end{array}$ \\
\hline & $27 / M$ & $\begin{array}{c}\text { *Slowly } \\
\text { progressive } \\
\text { proptosis over } 6 \\
\text { months }{ }^{*} 12 \mathrm{~mm} \text { of } \\
\text { proptosis } \\
\text { *Limitation on } \\
\text { elevation and } \\
\text { abduction } \\
{ }^{*} \text { Conjunctival } \\
\text { edema and } \\
\text { injection over the } \\
\text { LR muscle } \\
\text { insertion (OS) }\end{array}$ & $20 / 20$ & $\begin{array}{l}\text { *MRI: Well-defined tumor laterally } \\
\text { in the orbit with hypointense } \\
\text { signals on T1WI, hyperintense } \\
\text { signals on T2WI, and moderate } \\
\text { contrast enhancement }{ }^{*} \mathrm{CT} \text { scan: } \\
\text { No connection to the bony orbit }\end{array}$ & $\begin{array}{l}\text { Anterior } \\
\text { orbitotomy via a } \\
\text { superolateral } \\
\text { approach resulted } \\
\text { in resection of } \\
70 \% \text { of the tumor } \\
\text { + intensity } \\
\text { modulated } \\
\text { radiotherapy }\end{array}$ & $\begin{array}{l}{ }^{*} \text { At } 24 \text { months } \\
\text { F/U, VA was } \\
\text { 20/20, and there } \\
\text { was } 2 \text { mm of } \\
\text { residual proptosis }\end{array}$ \\
\hline $\begin{array}{l}\text { Decock } \\
\text { et } \mathrm{al}^{[3]}\end{array}$ & $66 / \mathrm{M}$ & $\begin{array}{l}\text { *4 years of } \\
\text { growing orbital } \\
\text { mass protruding } \\
\text { upper eyelid }{ }^{* A} \\
\text { firm mass not } \\
\text { adherent to bone } \\
\text { or skin (OS) }\end{array}$ & $20 / 20$ & $\begin{array}{l}{ }^{*} \text { CT scan: Extensively calcified } \\
\text { mass located at the anterior } \\
\text { edge of the lacrimal fossa } \\
\text { without hyperostosis or } \\
\text { involvement of the adjacent } \\
\text { orbital bone }\end{array}$ & $\begin{array}{l}\text { Translid surgical } \\
\text { approach }\end{array}$ & $\begin{array}{c}15 \text { months of } \mathrm{F} / \mathrm{U} \\
\text { without } \\
\text { recurrence }\end{array}$ \\
\hline \multirow[t]{4}{*}{$\begin{array}{l}\text { Huang } \\
\text { et al }{ }^{[13]}\end{array}$} & $7 / \mathrm{M}$ & $\begin{array}{c}\text { *5 months of } \\
\text { proptosis, upper } \\
\text { eyelid edema, and } \\
\text { diplopia }\end{array}$ & 1.2 & $\begin{array}{l}{ }^{*} \text { Coronal T1WI showed a } \\
\text { superonasal mass. Axial T2WI } \\
\text { showed an ill-defined and } \\
\text { heterogeneous mass and } \\
\text { adjacent MR. (Misdiagnosed as } \\
\text { capillary hemangioma) }\end{array}$ & $\begin{array}{l}\text { Complete surgical } \\
\text { resection in all } \\
\text { cases }\end{array}$ & $\begin{array}{l}\text { No recurrence or } \\
\text { diminution of } \\
\text { vision in none of } \\
\text { cases }\end{array}$ \\
\hline & $18 / F$ & $\begin{array}{l}{ }^{*} 24 \text { months of } \\
\text { proptosis, ptosis, } \\
\text { upper eyelid } \\
\text { edema, and } \\
\text { diplopia }\end{array}$ & 1.2 & $\begin{array}{c}{ }^{*} \text { Axial T1 showed an ill-defined } \\
\text { and heterogeneous superonasal } \\
\text { mass and adjacent MR } \\
\text { (Misdiagnosed as capillary } \\
\text { hemangioma) }\end{array}$ & & \\
\hline & 31/M & $\begin{array}{l}\text { *12 months of } \\
\text { proptosis, upper } \\
\text { eyelid edema, and } \\
\text { diplopia }\end{array}$ & LP & $\begin{array}{l}\text { *T1WI MRI was hypointense and } \\
\text { T2WI MRI was hyperintense } \\
\text { Axial CT scan showed a } \\
\text { well-defined intraconal mass } \\
\text { adjacent to the anterior optic } \\
\text { nerve (Misdiagnosed as } \\
\text { cavernous hemangioma) }\end{array}$ & & \\
\hline & $35 / M$ & $\begin{array}{l}* 72 \text { months of } \\
\text { proptosis, ptosis, } \\
\text { upper eyelid } \\
\text { edema, and } \\
\text { diplopia }\end{array}$ & 1.0 & $\begin{array}{c}{ }^{*} \text { Coronal T1 W1 showed the } \\
\text { superonasal mass and no } \\
\text { adjacent MR. Axial T1 W1 showed } \\
\text { the ill-defined and } \\
\text { heterogeneous superonasal } \\
\text { mass (Misdiagnosed as } \\
\text { eosinophilic granuloma) }\end{array}$ & & \\
\hline
\end{tabular}


Table 1. Continued

\begin{tabular}{|c|c|c|c|c|c|c|}
\hline No. ${ }^{[R e f]}$ & Patient & $\begin{array}{c}\text { History \& } \\
\text { Examination }\end{array}$ & VA & Imaging & Treatment & Outcome \\
\hline & $56 / M$ & $\begin{array}{l}\text { *3 months of } \\
\text { proptosis, ptosis, } \\
\text { upper eyelid } \\
\text { edema, and } \\
\text { diplopia }\end{array}$ & 1.0 & $\begin{array}{l}\text { *T1WI MRI was hypointense and } \\
\text { T2WI MRI was hyperintense } \\
{ }^{*} \text { Axial CT scan showed a } \\
\text { well-defined intraconal lesion } \\
\text { with a calcified mass. Optic } \\
\text { nerve was compressed and } \\
\text { dislocated but integrated into the } \\
\text { structure (Undiagnosed) }\end{array}$ & & \\
\hline & $52 / F$ & $\begin{array}{c}{ }^{*} 6 \text { months of } \\
\text { proptosis, ptosis, } \\
\text { upper eyelid } \\
\text { edema, and } \\
\text { diplopia }\end{array}$ & 0.5 & $\begin{array}{c}\text { *T1WI MRI was hypointense and } \\
\text { T2WI MRI was hyperintense (in } \\
\text { all } 6 \text { cases) (Misdiagnosed as } \\
\text { neurofibromatosis) }\end{array}$ & & \\
\hline \multirow[t]{3}{*}{$\begin{array}{l}\text { Pushker } \\
\text { et al }{ }^{[7]}\end{array}$} & $30 / F$ & $\begin{array}{l}\text { *18-month of } \\
\text { proptosis *3 mm } \\
\text { proptosis and } \\
\text { limitation in } \\
\text { elevation (OS) }\end{array}$ & $20 / 20$ & $\begin{array}{c}{ }^{*} \mathrm{CT} \text { scan: III-defined, } \\
\text { heterogenous enhancing soft } \\
\text { tissue mass involving the left } \\
\text { superior extraconal space }+ \\
\text { associated expansion and } \\
\text { sclerosis of the left half of the } \\
\text { frontal bone and roof of the left } \\
\text { orbit with few ill-defined lytic } \\
\text { lesions }\end{array}$ & $\begin{array}{l}\text { Excision through } \\
\text { the anterior } \\
\text { orbitotomy via a } \\
\text { sub-brow incision }\end{array}$ & $\begin{array}{l}{ }^{*} \text { Recurrence after } \\
8 \text { months resulted } \\
\text { in re-surgery }{ }^{*} \text { No } \\
\text { diminution of } \\
\text { vision and further } \\
\text { recurrence over } \\
\text { an 18-month } \\
\text { period }\end{array}$ \\
\hline & $40 / M$ & $\begin{array}{l}\text { *2-year history of } \\
\text { painless, } \\
\text { progressive } \\
\text { proptosis }{ }^{*} 6 \mathrm{~mm} \\
\text { of proptosis and } \\
\text { limitation in } \\
\text { elevation }(\mathrm{OS})\end{array}$ & $20 / 20$ & $\begin{array}{l}{ }^{*} \text { CT scan: Homogeneous } \\
\text { well-defined, intensely } \\
\text { enhancing soft tissue mass in the } \\
\text { left superomedial orbit }\end{array}$ & $\begin{array}{l}\text { Rupturing of mass } \\
\text { during excision } \\
\text { resulted in } \\
\text { piecemeal } \\
\text { removal }\end{array}$ & $\begin{array}{l}{ }^{*} \text { Recurrence of } \\
\text { the mass after } 11 \\
\text { months resulted } \\
\text { in re-surgery }{ }^{*} \mathrm{No} \\
\text { further recurrence } \\
\text { or diminished } \\
\text { vision over } 2 \\
\text { years F/U }\end{array}$ \\
\hline & $9 / \mathrm{M}$ & $\begin{array}{l}* 2.5 \text {-year history } \\
\text { of progressive } \\
\text { Proptosis }{ }^{*} 5 \mathrm{~mm} \\
\text { of proptosis with } \\
\text { (OS) }\end{array}$ & $20 / 20$ & $\begin{array}{c}{ }^{*} \mathrm{CT} \text { scan: Diffuse, mildly } \\
\text { enhancing and associated with } \\
\text { hyperplasia of the adjacent bone }\end{array}$ & $\begin{array}{c}\text { Piecemeal } \\
\text { removal }\end{array}$ & $\begin{array}{l}\text { No diminished } \\
\text { vision over } 3 \\
\text { months }\end{array}$ \\
\hline $\begin{array}{l}\text { Tendler } \\
\text { et al }{ }^{[11]}\end{array}$ & $9 / F$ & $\begin{array}{l}{ }^{*} \text { Gradual painless } \\
\text { swelling of the } \\
\text { medial upper } \\
\text { eyelid }{ }^{*} 2 \mathrm{~mm} \text { of } \\
\text { proptosis and a } \\
\text { firm mobile } \\
\text { palpable mass in } \\
\text { the superior nasal } \\
\text { orbit of the (OS) }\end{array}$ & $20 / 25$ & $\begin{array}{c}\text { *MRI: Extraconal enhancing mass } \\
\text { in the left medial orbit with } \\
\text { notable ethmoid sinus } \\
\text { asymmetry }\end{array}$ & $\begin{array}{l}\text { Excision }+ \text { proton } \\
\text { beam therapy and } \\
\text { surgical debulking } \\
\text { after recurrence }\end{array}$ & Not reported \\
\hline
\end{tabular}

VA, visual acuity; F, female; M, male; OD, right eye; OS, left eye; MRI, magnetic resonance imaging (MRI); CT scan, computed tomography scan; T1W1, T1-weighted image; T2W1, T2-weighted image; F/U, follow-up; CF, counting fingers; LP, light perception; $L R$, lateral rectus; $M R$, medial rectus

tumors may originate from congenitally dislocated nests of meningothelial cells, regressed orbital meningoceles located within the orbit, or curiously associated with dislocated meningeal tissues into the orbit secondary to penetrating injury or trauma. ${ }^{[10]}$ Interestingly, several reports exist regarding extracranial or extradural meningiomas found in unusual sites such as the neck, skin, finger, lung, mediastinum, and adrenal gland. ${ }^{[11]}$ 
Lee Teak Tan et al reported a case of presumed ectopic orbital meningioma which was decidedly diagnosed as olfactory groove meningioma. As a consequence, he hypothesized that a number of the previously reported cases have had similar scenarios of misdiagnosis. Having said that, other distinguished researchers continue to consider ectopic meningioma as a distinct entity where the origin and existence of ectopic orbital meningioma is still being debated. ${ }^{[12]}$

To date, there have been few reports of intraconal ectopic meningioma cases. A brief review of some of the recent reports of ectopic meningioma cases and other related issues such as demographic data, history, imaging findings, treatment, and final outcomes are summarized in Table 1.

The unique aspect of this case which has not been reported in prior studies is the development of an ectopic meningioma during pregnancy. This coincidental discovery on the possible association between pregnancy and the development and enlargement of meningiomatous tumors currently has no precedence and hence no available supporting data. However, it is recommended that treatment of these tumors be executed to ensure prevention of focal aggression. ${ }^{[1]}$ As a consequence, future case would need to be monitored to ensure all avenues are investigated.

In summary, as ectopic orbital meningiomas are characteristically very rare tumors and are not easily diagnosed with orbital imaging because of similar resemblance to other intraorbital tumors, serious consideration should be made in ensuring execution of postoperative histopathology to determine the existence or absence of these low prevalent tumors. The possible occurrence of these meningiomas should also be considered in the differential diagnosis of intraconal masses with hypointense signals on T1-weighted images and hyperintense signals on T2-weighted images. This approach would ensure the accurate diagnosis of conditions and would encourage the appropriate course of treatment.

\section{Financial Support and Sponsorship}

Nil.

\section{Conflicts of Interest}

There are no conflicts of interest.

\section{REFERENCES}

1. Bondy $\mathrm{M}$, Ligon BL. Epidemiology and etiology of intracranial meningiomas: a review. J Neurooncol 1996;29:197-205.

2. Lang FF, Macdonald OK, Fuller GN, DeMonte F. Primary extradural meningiomas: a report on nine cases and review of the CT-era literature. J Neurosurg 2000;93:940950.

3. Decock CE, Kataria S, Breusegem CM, Van Den Broecke $\mathrm{CM}$, Claerhout IJ. Ectopic meningioma anterior to the lacrimal gland fossa. Ophthalmic Plast Reconstr Surg 2009;25:57-59.

4. Arai KS, T. Matsumoto, H. Free-lying ectopic meningioma within the orbit. Br J Neurosurg 1997;11:560-563.

5. Farah SE, Konrad H, Huang DT, Geist CE. Ectopic orbital meningioma: a case report and review. Ophthalmic Plast Reconstr Surg 1999;15:463-466.

6. Johnson TE, Weatherhead RG, Nasr AM, Siqueira EB. Ectopic (extradural) meningioma of the orbit: a report of two cases in children. J Pediatr Ophthalmol Strabismus 1993;30:43-47.

7. Pushker N, Shrey D, Kashyap S, Sen S, Khurana S, Sharma S. Ectopic meningioma of the orbit. Int Ophthalmol 2013;33:707-710.

8. Tan K, Lim A. Primary extradural intra-orbital meningioma in a Chinese girl. Br J Ophthalmol 1965;49:377.

9. Yokoyama T, Nishizawa S, Sugiyama K, Yokota N, Ohta S, Uemura K, et al. Primary intraorbital ectopic meningioma. Skull Base Surg 1999;9:47-50.

10. Gündüz K, Kurt RA, Erden E. Ectopic orbital meningioma: report of two cases and literature review. Surv Ophthalmol 2014;59:643-648.

11. Tendler I, Belinsky I, Abramson DH, Marr BP. Primary extradural ectopic orbital meningioma. Ophthalmic Plast Reconstr Surg 2017;33:S99-S101.

12. Tan LT, Stewart CM, Sheerin F, MacDonald B, Silva P, Norris JH. Ectopic orbital meningioma: Fact or fiction? Orbit 2017;36:144-146.

13. Huang $X$, Tang $D$, Wu $T$, Jian $T$, Sun F. Ectopic orbital meningioma: a retrospective case series. BMC Ophthalmol 2018;18:296. 